\title{
Perancangan Mesin Bending untuk Menurunkan Reject Mechanical Packing Kapasitor
}

\author{
Benedikta Anna Haulian Siboro*, Vera Methalina Afma, Ardi Pratama Widyadana \\ Program Studi Teknik Industri, Fakultas Teknik, Universitas Riau Kepulauan Jl. Batu Aji Baru No.99 Batam, Kepulauan Riau \\ 29425 Indonesia
}

\section{ARTICLE INFORMATION}

Article history:

Received: December 18, 2017

Revised: June 22, 2018

Accepted: July 1, 2018

Kata Kunci:

Sistem Manusia Mesin

Waktu Baku

Uji T One-Way (Paired T-test)

\section{A B S T R A K}

Dalam upaya peningkatan produktivitas kerja diperlukan kesinergisan dan keseimbangan semua komponen dalam sistem kerja. Pencapaian produktivitas kerja melalui aktivitas berkelanjutan dilakukan pada salah satu perusahaan manufaktur yang memproduksi kapasitor. Pada proses packing dilakukan dengan cara manual menggunakan alat bantu bending yang menyebabkan kelelahan dengan persentase 90-95\% lelah pada kaki kanan dan tangan kanan, dengan rata-rata reject yang terjadi sebesar $14 \%$ dan hanya memenuhi $66 \%$ target output. Tujuan dari penelitian ini adalah membuat rancangan mesin bending untuk meningkatkan kapasitas proses packing , sehingga diharapkan dapat menurunkan reject mechanical dan secara tidak langsung menurunkan beban kerja pekerja. Perancangan mesin bending dilakukan pengujian statistik industri uji $\mathrm{T}$ (paired T-test) terhadap reject mechanical dengan membuat sistem mesin secara semi otomatis dengan motor dan kontrol mesin pada desain meja mesin menggunakan tinggi rata-rata duduk operator bertujuan agar waktu baku semakin cepat, beban kerja manusia berdasarkan sistem manusia mesin dapat menurun. Hasil dari perancangan mesin bending menunjukan bahwa waktu baku sesudah perancangan naik dari 1,52 detik menjadi 1,02 detik sehingga output rata-rata naik dari 16578 kapasitor menjadi 24705 kapasitor. Reject mechanical turun signifikan dari total rata-rata 2210 kapasitor menjadi total rata-rata 446 kapasitor dan beban kerja manusia dalam penelitian ini menurun dari 25,29 menit menjadi 6,23 menit sehingga target output dapat terpenuhi.

\section{A B S T R A C T}

In order to increase productivity required synergizing and balancing all components in the work system. The achievement of labor productivity through activity sustainable done at one manufacturing companies who produce capacitor. In the packing process is done manually using bending tools that cause fatigue $90-95 \%$ tired on the right foot and right hand, with the average reject $14 \%$ and only meet $66 \%$ output target. The purpose of this research is make a bending machine to increase the capacity process of packing, so it expected to decrease reject mechanical and indirectly decrease the work load operator. The design of the bending machine is done by testing the T-test statistic (paired T-test) against the mechanical reject by making the machine system semi-automatic with motor and engine control on the machine table design using the average height of the operator seat with the aim that the standard time can be faster, The human workload based on the man machine system may decrease. The result of bending machine design shows that the standard time after design is increased from 1.52 seconds to 1.02 seconds so the average output increase from 16578 capacitors to 24705 capacitors. The reject mechanical fell significantly from the average total of 2210 to an average total of 446 and the man workload in this study decreased from 25.29 minutes to 6.23 minutes, so the production target could be met. 


\section{PENDAHULUAN}

Manusia merupakan salah satu bagian terpenting dalam organisasi manufaktur [1]. Dalam mencapai tujuan menghasilkan produk yang berkualitas, manusia melakukan interaksi dengan mesin (sistem manusia-mesin) yang menghasilkan keluaran-keluaran berdasarkan masukan-masukan yang diperoleh [2]. Kaitan sistem manusia mesin terbagi menjadi 3 macam hubungan manusia mesin yaitu manual manmachine system, semi automatic man-machine system, dan automatic man-machine system. Manual man-machine system masukan (input) akan langsung ditransformasikan oleh manusia menjadi keluaran (output). Mesin dikendalikan penuh oleh manusia, mesin menjadi tambahan untuk menyelesaikan pekerjaan yang dibebankan kepada manusia (Gambar 1).

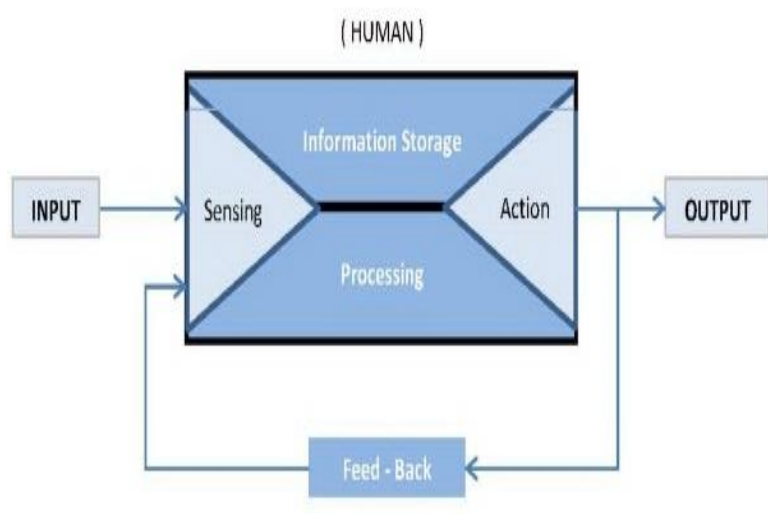

\section{Gambar 1. Diagram Manual Man-Machine System}

Dalam aktivitas pekerjaan, manusia mengalami beban kerja fisik dan beban kerja mental. Beban kerja fisik berhubungan dengan dengan kapasitas maksimum dari sistem fisiologi dalam menghasilkan energi untuk kerja otot seperti mengangkat, mendorong, memindahkan dan yang lain [3]. Beban kerja mental berhubungan dengan pekerjaan mental seseorang seperti menganalisis, menghitung dan yang lain [4]

Beban kerja manusia lebih tinggi dibandingkan dengan beban kerja mesin. Hal ini disebabkan oleh waktu penyelesaian pekerjaan lebih banyak daripada mesin itu sendiri. Waktu kerja yang dimaksud adalah mulai dari pengamatan terhadap kerja, set-up, proses kerja, informasi kerja, dan tindakan kerja seperti on/off mesin.

Mekanisme semiautomatic man-machine system yang dimiliki khusus mengolah masukan (input) atau informasi dari luar sebelum masuk ke dalam sistem manusia. Reaksi yang berasal dari sistem manusia akan diolah atau dikontrol terlebih dahulu melalui suatu mekanisme tertentu sebelum suatu output berhasil diproses. Skematis semiautomatic man-machine system dapat digambarkan dalam bagan sederhana seperti pada gambar 2

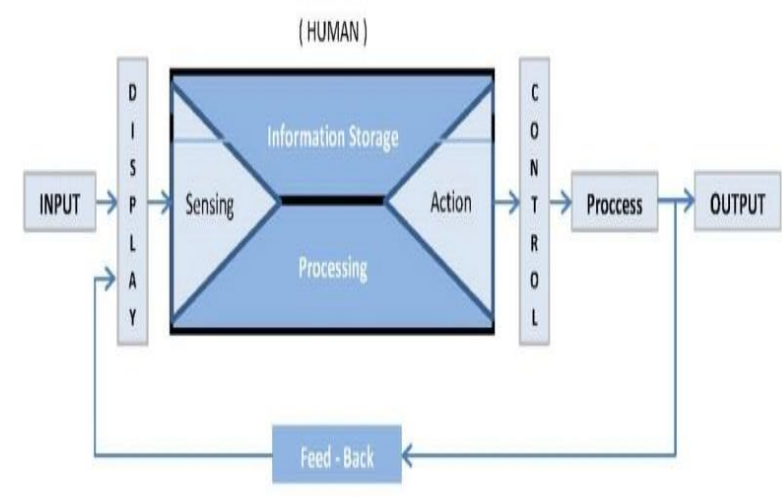

\section{Gambar 2. Diagram Semiautomatic Man- Machine System}

Kesesuaian interaksi manusia dengan teknologi yang digunakan dapat dilakukan dengan penerapan ilmu ergonomi [5]. Ergonomi dapat didefinisikan sebagai studi tentang aspek-aspek manusia dalam lingkungan kerjanya yang ditinjau secara anatomi, fisiologi, engineering, manajemen, dan desain/perancangan [6]

Penerapan ergonomi pada umumnya merupakan aktivitas rancang bangun (desain) ataupun rancang ulang (re-desain). Hal ini dapat meliputi perangkat keras seperti misalnya perkakas kerja, bangku kerja, platform, kursi, pegangan alat kerja, sistem pengendali, alat peraga, jalan/lorong, pintu, jendela dan lain-lain. Perancangan ulang kusri kerja dengan prinsip ergonomi mampu mengurangi rasa sakit yang dikeluhkan saat bekerja dan mengurangi tenaga yang dibutuhkan pekerja di departemen mesin bubut [7]

Pendekatan ergonomi mempunyai peranan penting dalam meningkatkan produktivitas dan menurunkan beban kerja pekerja [8]-[11]. Pendekatan ergonomi yang diamati adalah ergonomi kerja dengan posisi duduk dan gerakan manusia untuk mengidentifikasi permasalahan kelelahan pada operator.

Aktual proses bending kapasitor menggunakan alat bantu dalam melakukan proses packing kapasitor tersebut. Alat bantu packing ini 
dilakukan secara manual dengan menggunakan tangan dan kaki dalam melakukan proses packing terhadap kapasitor. Tangan untuk menggerakan feeding reel tape dengan perantara handle sedangkan kaki untuk menggerakan pressing unit untuk memotong dan membengkokan wire kapasitor sebelum dilakukan packing. Bentuk reel tape kapasitor yang akan dilakukan packing terlihat pada Gambar 3.

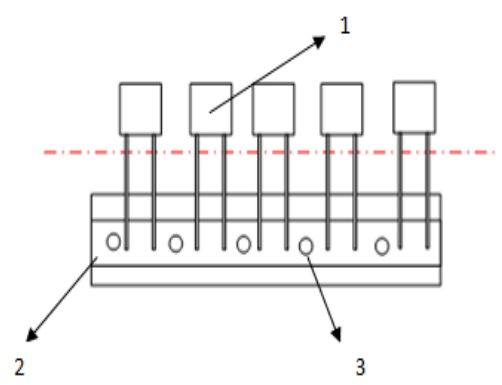

Keterangan :

1. Kapasitor

2. Reel tape

3. Hole tape

\section{Gambar 3 Reel Tape Kapasitor}

Berdasarkan pemaparan sebelumnya mengenai permasalahan proses bending manual yang mempengaruhi produktivitas dan menimbulkan keluhan kerja maka diperlukan sebuah rancangan mesin bending secara semi otomatis sehingga membantu meningkatkan produktivitas kerja serta membantu penurunan beban kerja karyawan.

\section{METODE PENELITIAN}

Obyek penelitian ini pada perusahaan manufaktur pada mesin packing bending yang hanya melakukan proses packing untuk produk kapasitor di kota Batam. Tahapan penelitian dilakukan mulai dari studi lapangan dan pengamatan secara langsung terhadap pekerja dalam mengoperasikan packing bending untuk mendapatkan identifikasi yang akan dijadikan sebagai landasan penelitian. Pengumpulan data dilakukan dengan observasi dan kuesioner

Kuesioner merupakan salah satu teknik pengumpulan data dalam bentuk pengajuan pertanyaan tertulis melalui sebuah daftar pertanyaan yang sudah dipersiapkan sebelumnya dan harus diisi oleh responden [12]. Kuesioner penelitian ini dilakukan untuk mengidentifikasi keluhan dari operator proses kerja yang bekerja pada proses packing bending yang berhubungan dengan manual handling proses. Data-data yang diperlukan untuk penelitian ini berupa data primer yang mencakup: a. Waktu rata-rata pekerja dalam menyelesaikan satu siklus pekerjaan packing bending

b. Beban kerja yang diambil dengan menggunakan metode sitstem manusia mesin.

c. Persentase reject mechanical sebelum dilakukan perancangan mesin bending.

Pengolahan data yang dilakukan dalam penelitian ini menggunakan :

1. Studi jam henti

Studi jam henti pada dasarnya penggunaan waktu untuk mengambil suatu sample kecil dari satu kegiatan karyawan dan menggunakannya untuk menentukan suatu standar bagi organisasi keseluruhan. Prosedur ringkas penggunaan metode jam henti adalah sebagai berikut [5] :

a. Melakukan penelitian pendahuluan

b. Mencatat waktu

c. Pengolahan data yaitu penentuan waktu baku yang didapat dari pengolahan data dengan rumus:

Waktu normal $\mathrm{x} \frac{100 \%}{100 \%-\% \text { Allowance }}$

2. Uji statistik

Statistik merupakan keterangan yang disusun atau disajikan dalam daftar atau gambar yang melukiskan atau menggambarkan sesuatu [13]. Pengujian statistik penelitian ini meliputi

a. Uji kecukupan data mengacu pada rumus dibawah ini untuk mencari nilai $N^{\prime}<N$ sehingga data dinyatakan cukup, bila didapat N'>N maka data harus diambil ulang [6]

$$
N^{\prime}=\left[\frac{\frac{k}{s} \sqrt{N \cdot \sum X i^{2}-\left(\sum X i\right)^{2}}}{\sum X i}\right]^{2}
$$

$N^{\prime} \quad$ : jumlah pengukuran yang diperlukan

$N$ : jumlah pengkuran yang telah dilakukan

$k$ : tingkat kepercayaan

$s$ : tingkat ketelitian

$\mathrm{Xi}$ : data yang telah diukur

b. Uji keseragaman data mengacu pada rumus di bawah ini untuk mencari nilai standar deviasi

$\sigma=\sqrt{\frac{(\mathrm{Xj}-\bar{X})^{2}+\cdots+(\mathrm{Xn}-\bar{X})^{2}}{\mathrm{n}-1}}$

dimana :

$\sigma \quad:$ standar deviasi

$X j$ : hasil pengukuran data ke j

$\bar{X}$ : hasil pengukuran rata - rata.

$n$ : banyaknya pengukuran 
c. Penentuan BKA (Batas Kontrol Atas) dan BKB (Batas Kontrol Bawah) sehingga data yang berada antara BKA dan BKB data dinyatakan seragam dan data yang keluar dari daerah batas harus dilakukan uji kecukupan data lagi sebelum melakukan uji keseragaman data terhadap data pengganti.

$B K A=\bar{X}+3 \sigma \mathrm{x}$
$B K B=\bar{X}-3 \sigma \mathrm{x}$

d. Uji-T Hipotesis (One-Way Test)

Sifat komplementer dari hipotesis sesuai dengan gambar 4 .

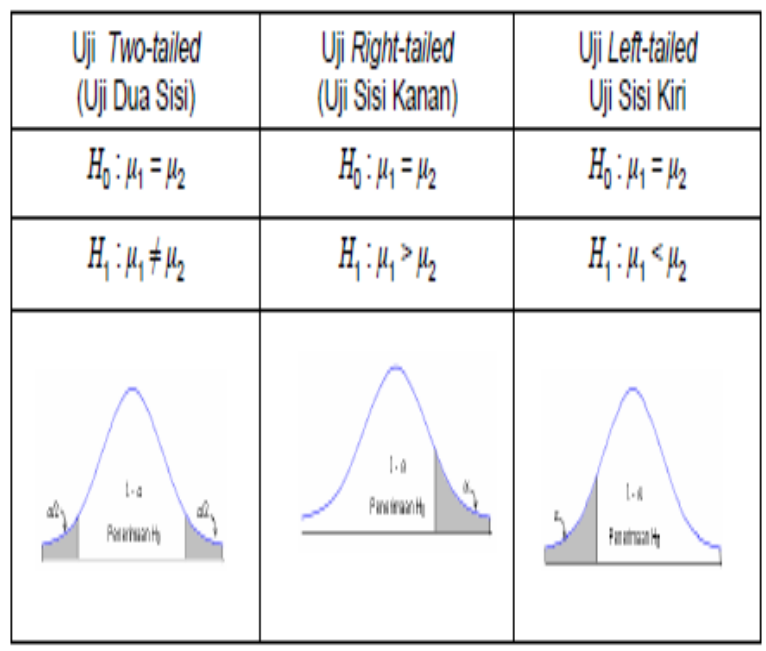

Gambar 4. Arah Pengujian Hipotesis

Tujuan hasil penelitian adalah $\mathrm{HO}: \pi 1=\pi 0$ artinya tidak terdapat perbedaan rata-rata reject sebelum dan sesudah perancangan atau $\mathrm{HO}: \pi 1 \neq \pi 0$ artinya terdapat perbedaan rata-rata reject sebelum dan sesudah perancangan dengan nilai $T_{\text {hitung }}$ lebih besar dari nilai $\mathrm{T}_{\text {tabel }}$ yang berarti $\mathrm{H} 1$ diterima dan $\mathrm{Ho}$ ditolak.

e. Pengendalian kualitas

Penelitain ini mencoba untuk mengendalikan reject mechanical yang dihadapi dengan menggunakan diagram pareto untuk mendapatkan perbandingan persentase sebelum dan sesudah perancangan. Metode dasar untuk pelaksanaan pengendalian kualitas adalah penggunaan metode statistik yang berupa bagan pengendalian dan inspeksi berdasarkan sampling [14].

\section{HASIL DAN PEMBAHASAN}

Dari penelitian ini didapatkan keluhan nyeri tangan kanan dan kaki kanan proses aktual manual berdasarkan teori biomekanika yaitu gerak fleksi dan ekstensi sendi siku melebihi sudut $90^{\circ}-120^{\circ}$ yaitu $130^{\circ}$, lebar genggaman tangan kurang dari $4-5 \mathrm{~cm}$ yaitu $3 \mathrm{~cm}$ dan posisi ekstensi lutut kaki kurang dari sudut $160^{\circ}$ yaitu $95^{\circ}$ dan kuesioner yaitu menyatakan $90 \%$ lelah pada tangan sebelah kanan dan lelah pada kaki sebelah kanan menyebabkan reject bentlead $6 \%$, box crack $5 \%$ dan broken stand $3 \%$ dari total output sebab kondisi kelelahan tersebut antara handling feeding tape yang menggunakan tangan dengan kontrol pressing yang dikendalikan oleh kaki menyebabkan tape tersangkut dan posisi kapasitor yang tidak tepat didudukan pressing (Gambar 5).

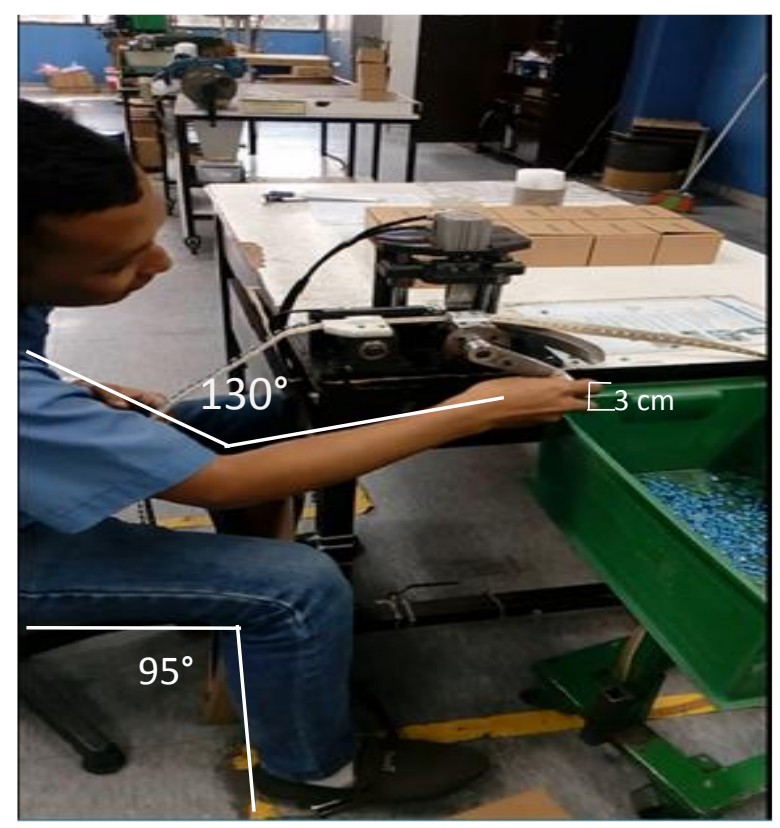

Gambar 5. Identifikasi Keluhan Berdasarkan Teori Dinamika

Identifikasi 2 item dari gerakan tangan kanan dan kaki kanan pada gambar di atas yang melakukan proses kerja tersebut penulis amati berdasarkan teori biomekanika yaitu :

1. Gerak fleksi dan ekstensi sendi siku tangan melebihi sudut $90^{\circ}-120^{\circ}$ yaitu $130^{\circ}$.

2. Lebar genggaman tangan kurang dari $4-5$ $\mathrm{cm}$ yaitu $3 \mathrm{~cm}$.

3. Posisi ekstensi lutut kaki kurang dari sudut $160^{\circ}$ yaitu $95^{\circ}$.

Data beban kerja sebelum perancangan mesin packing bending dalam menyelesaikan 1 reel yang berisi 1000 kapasitor adalah beban kerja manusia lebih banyak bekerja terhadap proses packing bending kapasitor dengan waktu kerja proses 25,29 menit dibandingkan dengan mesin yang hanya bekerja dengan waktu 15,76 menit, terdapat selisih waktu 9,53 menit. Pembebanan 
kerja yang berlebihan juga dapat mengakibatkan kelelahan kerja. Sarana kerja yang tidak antropometris dan waktu kerja yang panjang dapat memberikan tambahan beban kerja dan menimbulkan terjadinya kelelahan dini, bahkan dapat berakibat fatal bagi kesehatan pekerja [15].

Dari 4 waktu siklus operator maka, waktu siklus proses rata-rata untuk menghasilkan 1 packing bending kapasitor adalah total waktu siklus dibagi dengan jumlah operator yang diambil sample waktu proses rata-rata kerja yaitu 4 maka waktu siklus proses kerja rata-rata adalah 1,28 detik, dari waktu siklus maka didapat waktu standar atau waktu baku dan output rata-rata setiap shift (7 jam kerja) yaitu: 1,52 detik dengan output ratarata setiap shift yaitu 16578 kapasitor.

Aktual reject mechanical yang terjadi mengacu pada data dari sorting daily OQA (Outgoing Quality Assurance) yang terbagi menjadi 3 kriteria reject yaitu critical reject, major reject dan minor reject dengan persentase reject mechanical dengan menggunakan diagram pie chart pada Gambar 6.

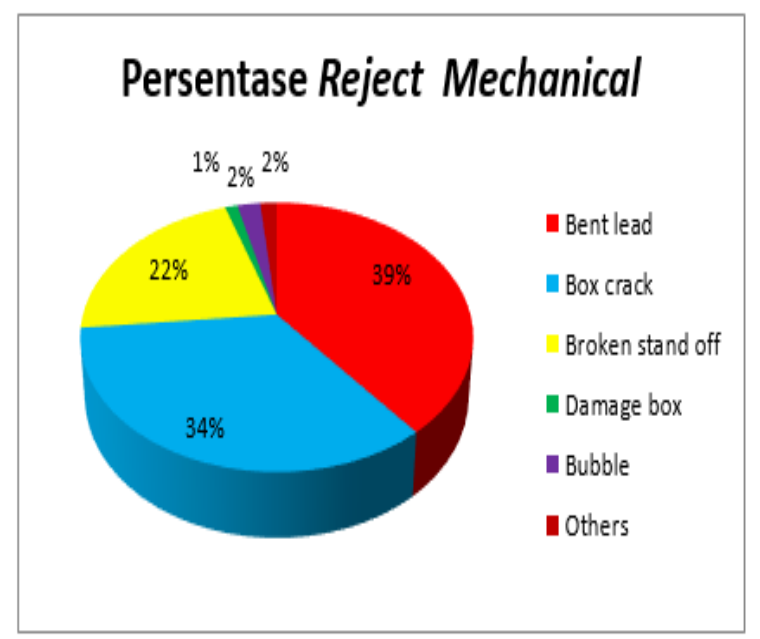

\section{Gambar 6. Diagram Pie Chart Aktual Reject Mechanical Kapasitor}

Reject mechanical aktual yang paling besar dari keseluruhan jumlah reject sebesar $100 \%$ adalah reject bent lead dengan $39,25 \%$, reject box crack dengan $34,15 \%$ dan reject broken stand off dengan $21,57 \%$ dari keseluruhan rata-rata reject yang terjadi sebanyak 2512 kapasitor. Proses terjadinya reject mechanical yang akan diturunkan adalah sebagai berikut :

\section{Bentlead}

Proses secara manual diidentifikasi bahwa reject mechanical yang tinggi disebabkan karena beban kerja manusia yang tinggi (untuk 1 reel terdiri dari 1000 kapasitor manusia bekerja 25,29 menit sedangkan mesin bekerja 15,76 menit) terhadap mesin sehingga tekanan tidak stabil ( $<2,5$ bar) membuat tidak maksimalnya kontrol pressing dengan menggunakan kaki, membuat bentlead akibat cutting pressing unit tidak memotong wire dengan maksimal (Gambar 7).

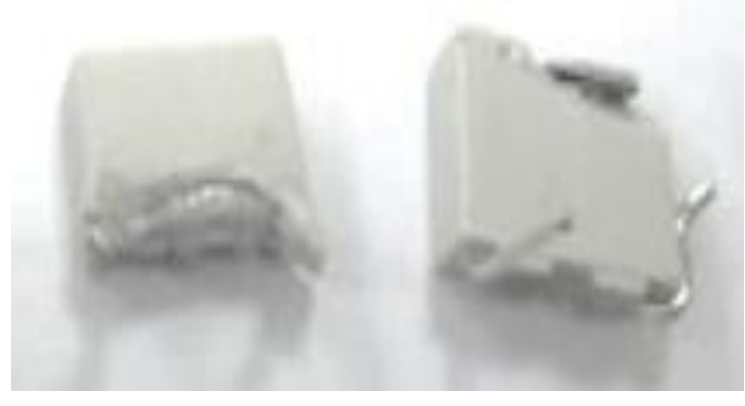

Gambar 7. Reject Bentlead Packing Kapasitor

\section{Box Crack}

Dari identifikasi masalah kelelahan proses manual berdasarkan teori biomekanika (gerak fleksi dan ekstensi sendi siku melebihi sudut 900 - $120^{\circ}$ yaitu $130^{\circ}$, lebar genggaman tangan kurang dari $4-5 \mathrm{~cm}$ yaitu $3 \mathrm{~cm}$ dan posisi ekstensi lutut kaki kurang dari sudut $160^{\circ}$ yaitu $95^{\circ}$ ) dan kuesioner (menyatakan 90\% lelah pada tangan sebelah kanan dan lelah pada kaki sebelah kanan) menyebabkan reject box crack yaitu tergoresnya box kapasitor (Gambar 8).
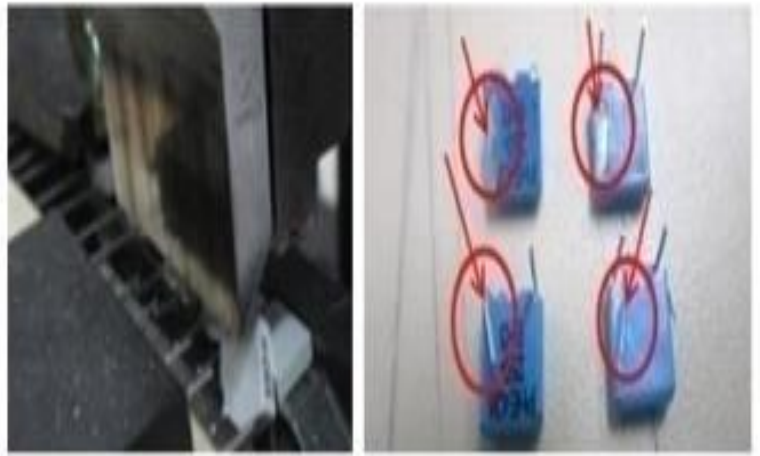

Gambar 8. Reject Damage Box Packing Kapasitor

\section{Broken Stand Off}

Posisi kapasitor yang tidak pada dudukan feeding menyebabkan reject broken stand off, dimana stand off kapasitor keluar dari jalur feeding reel tape saat pressing unit akan turun untuk membengkokan dan memotong wire kapasitor membuat stand off pecah (Gambar 9). 


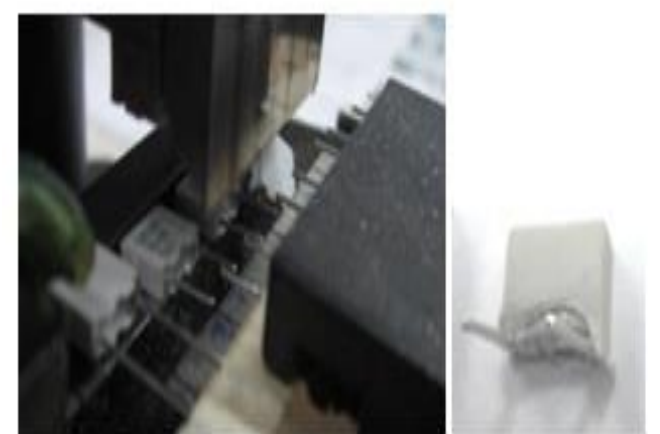

Gambar 9. Reject Broken Stand Off Kapasitor

Rangkaian elektronik digunakan untuk mengendalikan alat bantu proses packing bending dari penggunaan secara manual menjadi semi otomatis dan meja yang digunakan sebelum perancangan digunakan juga untuk proses screening. Meja mesin dirancang dengan menggunakan tinggi rata-rata duduk operator, sehingga meja mesin untuk proses packing bending kapasitor dengan meja yang digunakan untuk proses screening area dapat dipisahkan (Gambar 10).

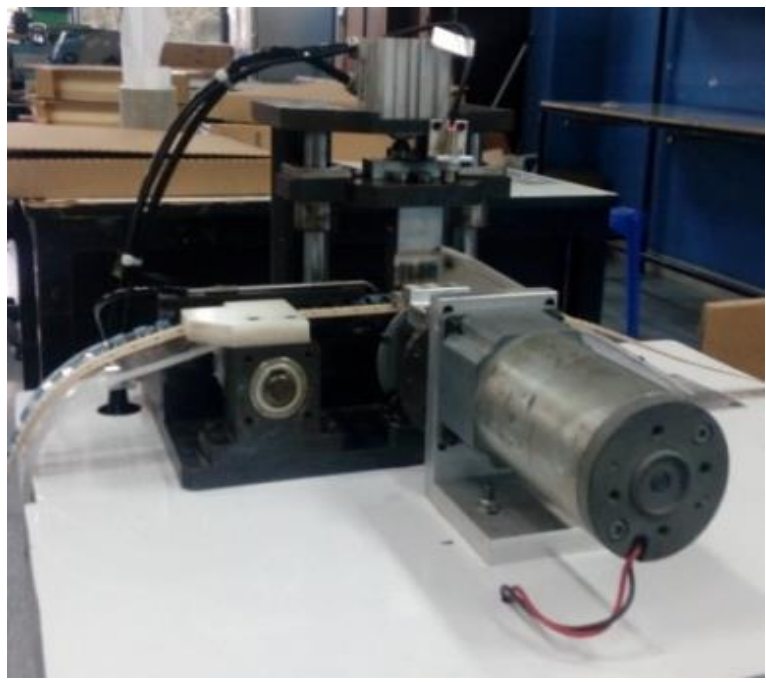

Gambar 10. Hasil Perancangan Mesin Packing Bending Kapasitor

Hasil perancangan mesin packing bending kapasitor secara semi otomatis melakukan proses kerja yaitu memproses setiap reel tape yang berisi 1000 kapasitor. Gerakan feeding reel tape menggunakan motor dengan kontrol relay sebagai pengontrol dengan bekerjanya fungsi sensor photo electric yang dipasang pada sliding part. Gerakan pressing unit dikontrol juga dengan relay dengan menggunakan sensor photo electric yang akan mendeteksi kapasitor yang akan dilakukan pressing, letak sensor photo electric untuk mengontrol gerakan pressing unit ini dipasang di atas dudukan feeding reel tape.

Perbandingan proses packing bending menggunakan alat bantu sebelum perancangan dengan sistem semi otomatis sesudah perancangan dapat dilihat pada tabel 1 .

Tabel 1 Perbandingan Proses Packing Bending Sebelum Dan Sesudah Perancangan

\begin{tabular}{|c|c|c|c|c|}
\hline No & Bagian & $\begin{array}{c}\text { Sebelum } \\
\text { Perancangan }\end{array}$ & \multicolumn{2}{|c|}{$\begin{array}{c}\text { Sesudah } \\
\text { Perancangan }\end{array}$} \\
\hline 1 & Sistem & Manual & Semi otomatis & \\
\hline 2 & $\begin{array}{l}\text { Gerakan } \\
\text { feeding } \\
\text { unit }\end{array}$ & $\begin{array}{l}\text { Digerakan oleh } \\
\text { tangan kanan } \\
\text { menggunakan } \\
\text { handle }\end{array}$ & $\begin{array}{l}\text { Digerakan } \\
\text { motor } \\
\text { dikendalikan } \\
\text { box pengendali }\end{array}$ & $\begin{array}{r}\text { oleh } \\
\text { yang } \\
\text { oleh }\end{array}$ \\
\hline 3 & $\begin{array}{l}\text { Gerakan } \\
\text { pressing } \\
\text { unit }\end{array}$ & $\begin{array}{l}\text { Digerakan oleh } \\
\text { kaki kanan } \\
\text { menggunakan } \\
\text { pedal }\end{array}$ & $\begin{array}{l}\text { Dikontrol } \\
\text { menggunakan } \\
\text { pengendali } \\
\text { sensor photo el }\end{array}$ & $\begin{array}{l}\text { box } \\
\text { dari } \\
\text { ectric }\end{array}$ \\
\hline
\end{tabular}

Berikut adalah hasil perbandingan sebelum dan sesudah perancangan dengan sistem semi otomatis sebagai berikut :

Perbandingan beban kerja berdasarkan sistem manusia mesin sebelum dan sesudah perancangan mesin packing bending kapasitor secara semi otomatis dapat dilihat pada Tabel 2.

Tabel 2. Perbandingan Beban Kerja Berdasarkan Sistem Manusia Mesin Sebelum Dan Sesudah Perancangan

\begin{tabular}{lllc}
\hline \multirow{2}{*}{ No } & Objek & \multicolumn{2}{c}{ Beban Kerja (menit) } \\
\cline { 3 - 4 } & & $\begin{array}{c}\text { Sebelum } \\
\text { perancangan }\end{array}$ & $\begin{array}{c}\text { Sesudah } \\
\text { perancangan }\end{array}$ \\
\hline 1 & Manusia & 25.29 & 6.23 \\
2 & Mesin & 15.76 & 10.79 \\
\hline
\end{tabular}

Beban kerja manusia menurun setelah dilakukan perancangan yaitu 6,23 menit dari sebelum perancangan yaitu 25,29 menit dengan selisih 19,06 menit. Perbandingan waktu standar atau waktu baku yang dilakukan operator untuk menyelesaikan satu waktu proses packing bending dengan menyelesaikan 1 kapasitor sebelum dan sesudah perancangan dapat dilihat pada tabel 3: 
Tabel 3. Perbandingan Waktu Baku Sebelum Dan Sesudah Perancangan

\begin{tabular}{llcc}
\hline No & Item & $\begin{array}{c}\text { Sebelum } \\
\text { perancangan }\end{array}$ & $\begin{array}{c}\text { Sesudah } \\
\text { perancangan }\end{array}$ \\
\hline $\begin{array}{l}\text { Waktu } \\
\text { baku }\end{array}$ & 1.52 detik & 1.02 detik
\end{tabular}

Waktu baku sesudah perancangan naik dari 1,52 detik menjadi 1,02 detik yang artinya waktu yang dibutuhkan untuk menyelesaikan 1 kapasitor proses packing bending semakin cepat dengan selisih kenaikan waktu 0,50 detik. Untuk perbandingan persentase reject mechanical berdasarkan daerah parreto diagram 80:20 yang terjadi pada proses packing bending kapasitor sebelum dan sesudah perancangan dapat dilihat pada tabel di bawah ini :

Tabel 4 Perbandingan Persentase Reject Mechanical Sebelum Dan Sesudah Perancangan

\begin{tabular}{llll}
\hline \multirow{2}{*}{ No } & Reject & \multicolumn{2}{c}{ Rata-rata } \\
\cline { 3 - 4 } & & $\begin{array}{c}\text { Sebelum } \\
\text { perancangan }\end{array}$ & $\begin{array}{c}\text { Sesudah } \\
\text { perancangan }\end{array}$ \\
\hline 1 & Bentlead & 957 & 145 \\
2 & Box crack & 815 & 211 \\
& Broken & & 90 \\
3 & stand off & 438 & 446 \\
\hline \multicolumn{2}{l}{ Total } & 2210 & \\
\hline
\end{tabular}

Dari tabel 4. total rata-rata reject mechanical (daerah 80:20 parreto diagram) yang terjadi sesudah perancangan menurun secara signifikan dari total rata-rata 2210 atau $13,39 \%$ dengan rata-rata output 16500 sebelum perancangan menjadi total rata-rata 446 atau $1,8 \%$ reject mechanical yang terjadi dengan output rata-rata 24700 dalam 7 jam kerja. Dari $\mathrm{T}_{\text {hitung }}$ didapat hasil 245,92 sedangkan $T_{\text {tabel }}$ didapat dengan derajat bebas yaitu $\mathrm{Df}=\mathrm{n}-1, \mathrm{Df}=15-1=14$ dan tingkat signifikan yang penulis gunakan 0,05 adalah sebesar 1,761 . Jadi, $T_{\text {hitung }}>T_{\text {tabel }}$ yaitu $245,92>1,761$,karena $T_{\text {hitung }}$ lebih besar dari $\mathrm{T}_{\text {tabel }}$ sesuai dengan hipotesis berarti $\mathrm{H} 1$ diterima dan $\mathrm{HO}$ ditolak artinya perancangan diterima.

\section{KESIMPULAN}

Berdasarkan analisis pengolahan data dapat disimpulkan bahwa rancangan mesin bending secara semi otomatis dapat meningkatkan kapasitas proses packing produk kapasitor dengan waktu baku sesudah perancangan naik dari 1,52 detik menjadi 1,02 detik. Penurunan reject mechanical yang terjadi sesudah perancangan menurun secara signifikan dari $13,39 \%$ menjadi rata-rata $1,8 \%$. Perbandingan beban kerja manusia menurun setelah dilakukan perancangan yaitu 6,23 menit dari sebelum perancangan 25,29 menit.

\section{DAFTAR PUSTAKA}

[1] R. Sharma, "Conceptual framework for improving business performance with lean manufacturing and successful human factors interventions-a case study," Int. J. Qual. Res., vol. 6, no. 3, pp. 259-270, 2012.

[2] S. Wignjosoebroto, Pengantar Teknik dan Manajemen Industri. Surabaya: Guna Widya, 2003.

[3] F. Tayyari and J. L. Smith, Occupational ergonomics: Principles and applications (Manufacturing systems engineering series). United Kingdom: Chapman \& Hall London, 1997.

[4] A. F. Hima and M. K. Umami, "Evaluasi Beban Kerja Operator Mesin pada Departemen Log and Veeeneer Preparation di PT. XYZ," J. Tek. dan Manaj. Ind., vol. 6, no. 2, pp. 106-113, 2011.

[5] T. H. Handoko, Dasar-dasar manajemen produksi dan operasi. Yogyakarta: BPFE, 2010.

[6] E. Nurmianto, Ergonomi. Konsep Dasar dan Aplikasinya. Surabaya: Guna Widya, 2004.

[7] S. Wignjosoebroto, A. Rahman, and D. Pramono, "Perancangan Lingkungan Kerja dan Alat Bantu yang Ergonomis untuk Mengurangi Masalah Back Injury dan Tingkat Kecelakaan Kerja pada Departemen Mesin Bubut," J. Inst. Teknol. Sepuluh Nop. (ITS). Surabaya, vol. 8, no. 7, pp. 1-11, 2006.

[8] A. Kristanto and R. Manopo, "Perancangan ulang fasilitas kerja pada stasiun cutting yang ergonomis guna memperbaiki posisi kerja operator sebagai upaya peningkatan produktivitas kerja studi kasus di perusahaan anode crome yogyakarta," J. Inform., vol. 4, no. 2, pp. 467-479, 2010.

[9] A. Kristanto and S. C. Widodo, "Perancangan ulang alat perontok padi yang ergonomis untuk meningkatkan produktivitas dan kualitas kebersihan padi," J. IIm. Tek. Ind., vol. 14, no. 1, pp. 78-85, 2015. 
[10] N. Nofirza and D. Syahputra, "Perancangan alat pemotong nenas yang ergonomis untuk meningkatkan produktivitas," J. IIm. Tek. Ind., vol. 11, no. 1, pp. 41-50, 2012.

[11] T. Rochman, R. D. Astuti, and R. Patriansyah, "Peningkatan produktivitas kerja operator melalui perbaikan alat material handling dengan pendekatan ergonomi," PERFORMA Media IIm. Tek. Ind., vol. 9, no. 1, pp. 1-10, 2010.

[12] S. A. Muhidin and M. Abdurahman, Analisis korelasi, regresi, dan jalur dalam penelitian. Bandung: Pustaka Setia, 2007.

[13] A. Fauzy, Statistik Industri. Jakarta: Erlangga, 2008.

[14] J. Supranto, Teknik sampling untuk survei dan eksperimen. Jakarta: Rineka Cipta, 2000.

[15] B. Sugeng, R. M. S. Jusuf, and A. Pusparini, Bunga Rampai Hiperkes dan Keselamatan Kerja. Semarang: Badan Penerbit Universitas Diponegoro, 2003. 